\title{
INDIA - NEPAL TREATY CONCERNING THE INTEGRATED DEVELOPMENT OF THE MAHAKALI RIVER INCLUDING SARADA BARRAGE, TANAKPUR BARRAGE AND PANCHESWAR PROJECT New Delhi, 12 February $1996^{*}$
}

Recognizing that the Mahakali River is a boundary river on major stretches between the two countries;

Realizing the desirability to enter into a treaty on the basis of equal partnership to define their obligations and corresponding rights and duties thereto in regard to the waters of the Mahakali River and its utilization;

Noting the Exchange of Letters of 1920 through which both the Parties had entered into an arrangement for the construction of the Sarada Barrage in the Mahakali River, whereby Nepal is to receive some waters from the said Barrage;

Recalling the decision taken in the Joint Commission dated 4-5 December, 1991 and the Joint Communique issued during the visit of the Prime Minister of India to Nepal on 21st October, 1992 regarding the Tanakpur Barrage which India has constructed in a course of the Mahakali River with a part of the eastern afflux bund at Jimuwa and the adjoining pondage area of the said Barrage lying in the Nepalese territory;

Noting that both the parties are jointly preparing a Detailed Project Report of the Pancheshwar Multipurpose Project to be implemented in the Mahakali River;

Now, therefore, the Parties hereto hereby have agreed as follows:

\section{Article 1}

1. Nepal shall have the right to a supply of $28.35 \mathrm{~m} 3 / \mathrm{s}$ (1000 cusecs) of water from the Sarada Barrage in the wet season (i.e. from 15th May to 15 th October) and $4.25 \mathrm{~m} 3 / \mathrm{s}(150$ cusecs) in the dry season (i.e. from 16th October to 14th May).

2. India shall maintain a flow of not less than $10 \mathrm{~m} 3 / \mathrm{s}$ (350 cusecs) downstream of the Sarada Barrage in the Mahakali River to maintain and preserve the river eco-system.

3. In case the Sarada Barrage becomes non-functional due to any cause:

\section{* Courtesy of the Minister of Water Resources of Nepal.}

The notes exchanged on the same date between the two prime ministers are not reproduced. The notes recall certain items in the Treaty previously regulated on 4-5 Dec. 1991 by the Joint Commission and governed by the Prime Ministers' Joint Communique of 21 October 1992. 
a) Nepal shall have the right to a supply of water as mentioned in Paragraph 1of this Article, by using the head regulator(s) mentioned in Paragraph 2 of Article 2 herein.

Such a supply of water shall be in addition to the water to be supplied to Nepal pursuant to Paragraph 2 of Article 2.

(b) India shall maintain the river flow pursuant to Paragraph 2 of this Article from the tailrace of the Tanakpur Power Station downstream of the Sarada Barrage.

\section{Article 2}

In continuation of the decisions taken in the Joint Commission dated 4-5 December, 1991 and the Joint Communique issued during the visit of the Prime Minister of India to Nepal on 21st October, 1992, both the Parties agree as follows:

1. For the construction of the eastern afflux bund of the Tanakpur Barrage, at Jimuwa and tying it up to the high ground in the Nepalese territory at EL $250 \mathrm{M}$, Nepal gives its consent to use a piece of land of about 577 metres in length (an area of about 2.9 hectares) of the Nepalese territory at the Jimuwa Village in Mahendranagar Municipal area and a certain portion of the No-Man's Land on either side of the border. The Nepalese land consented to be so used and the land lying on the west of the said land (about 9 hectares) upto the Nepal-India border which forms a part of the pondage area, including the natural resources endowment lying within that area, remains under the continued sovereignty and control of Nepal and Nepal is free to exercise all attendant rights thereto.

2. In lieu of the eastern afflux bund of the Tanakpur Barrage, at Jimuwa thus constructed, Nepal shall have the right to:

(a) a supply of $28.35 \mathrm{~m} 3 / \mathrm{s}$ (1000 cusecs) of water in the wet season (i.e. from 15th May to 15 th October) and $8.50 \mathrm{~m} 3 / \mathrm{s}$ (300 cusecs) in the dry season (i.e. from 16th October to 14th May) from the date of the entry into force of this Treaty. For this purpose and for the purposes of Article 1 herein, India shall construct the head regulator(s) near the left undersluice of the Tanakpur Barrage and also the waterways of the required capacity upto the Nepal-India border. Such head regulator(s) and waterways shall be operated jointly.

(b) a supply of 70 millions kilowatt-hour (unit) of energy on a continuous basis annually, free of cost, from the date of the entry into force of this Treaty. For this purpose, India shall construct a $132 \mathrm{Kv}$ transmission line upon the Nepal-India border from the Tanakpur Power Station (which has, at present, an installed capacity of 120,000 kilowatt generating 448.4 millions kilowatt-hour of energy annually on 90 percent dependable year flow).

3. Following arrangements shall be made at the Tanakpur Barrage at the time of development of any storage project(s) including Pancheshwar Multi-purpose Project upstream of the Tanakpur Barrage:

(a) Additional head regulator and the necessary waterways, as required, up to the Nepal-India border shall be constructed to supply additional water to Nepal. Such head regulator and waterways shall be operated jointly.

(b) Nepal shall have additional energy equal to half of the incremental energy generated from the Tanakpur Power Station, on a continuous basis from the date of augmentation of the flow of the Mahakali River and shall bear half of the additional operation cost and, if required, half of the additional capital cost at the Tanakpur Power Station for the generation of such incremental energy. 


\section{Article 3}

Pancheshwar Multipurpose Project (hereinafter referred to as the 'Project') is to be constructed on a stretch of the Mahakali River where it forms the boundary between the two countries and hence both the Parties agree that they have equal entitlement in the utilization of the waters of the Mahakali River without prejudice to their respective existing consumptive uses of the waters of the Mahakali River. Therefore, both the Parties agree to implement the Project in the Mahakali River in accordance with the Detailed Project Report (DPR) being jointly prepared by them. The Project shall be designed and implemented on the basis of the following principles:

1. The Project shall, as would be agreed between the Parties, be designed to produce the maximum total net benefit. All benefits accruing to both the Parties with the development of the Project in the forms of power, irrigation, flood control etc., shall be assessed.

2. The Project shall be implemented or caused to be implemented as an integrated project including power stations of equal capacity on each side of the Mahakali River. The two power stations shall be operated in an integrated manner and the total energy generated shall be shared equally between the Parties.

3. The cost of the Project shall be borne by the Parties in proportion to the benefits accruing to them. Both the Parties shall jointly endeavour to mobilize the finance required for the implementation of the Project.

4. A portion of Nepal's share of energy shall be sold to India. The quantum of such energy and its price shall be mutually agreed upon between the Parties.

\section{Article 4}

India shall supply $10 \mathrm{~m} 3 / \mathrm{s}$ (350 cusecs) of water for the irrigation of Dodhara-Chandani area of Nepalese Territory. The technical and other details will be mutually worked out.

\section{Article 5}

1. Water requirements of Nepal shall be given prime consideration in the utilization of the waters of the Mahakali River.

2. Both the Parties shall be entitled to draw their share of waters of the Mahakali River from the Tanakpur Barrage and/or other mutually agreed points as provided for in this Treaty and any subsequent agreement between the Parties.

\section{Article 6}

Any project, other than those mentioned herein, to be developed in the Mahakali River, where it is a boundary river, shall be designed and implemented by an agreement between the Parties on the principles established by this Treaty.

\section{Article 7}

In order to maintain the flow and level of the waters of the Mahakali River, each Party undertakes not to use or obstruct or divert the waters of the Mahakali River adversely affecting its natural flow and level except by an agreement between the Parties. Provided, 
however, this shall not preclude the use of the waters of the Mahakali River by the local communities living along both sides of the Mahakali River, not exceeding five (5) percent of the average annual flow at Pancheshwar.

\section{Article 8}

This Treaty shall not preclude planning, survey, development and operation of any work on the tributaries of the Mahakali River, to be carried out independently by each Party in its own territory without adversely affecting the provision of Article 7 of this Treaty.

\section{Article 9}

1. There shall be a Mahakali River Commission (hereinafter referred to as the 'Commission'). The Commission shall be guided by the principles of equality, mutual benefit and no harm to either Party.

2. The Commission shall be composed of an equal number of representatives from both the Parties.

3. The functions of the Commission shall, inter alia, include the following:

(a) To seek information on and, if necessary, inspect all structures included in the Treaty and make recommendations to both the Parties to take steps which shall be necessary to implement the provisions of this Treaty.

(b) To make recommendations to both the Parties for the conservation and utilization of the Mahakali River as envisaged and provided for in this Treaty.

(c) To provide expert evaluation of projects and recommendations thereto.

(d) To co-ordinate and monitor plans of actions arising out of the implementation of this Treaty, and

(e) To examine any differences arising between the Parties concerning the interpretation and application of this Treaty.

4. The expenses of the Commission shall be borne equally by both the Parties.

5. As soon as the Commission has been constituted pursuant to Paragraphs 1 and 2 of this Article, it shall draft its rules of procedure which shall be submitted to both the Parties for their concurrence.

6. Both the Parties shall reserve their rights to deal directly with each other on matters which may be in the competence of the Commission.

\section{Article 10}

Both the Parties may form project specific joint entity/ies for the development, execution and operation of new projects including Pancheshwar Multipurpose Project in the Mahakali River for their mutual benefit.

\section{Article 11}

1. If the Commission fails under Article 9 of this Treaty to recommend its opinion after examining the differences of the Parties within three (3) months of such reference to the 
Commission or either Party disagrees with the recommendation of the Commission, then a dispute shall be deemed to have been arisen which shall then be submitted to arbitration for decision. In so doing either Party shall give three (3) months prior notice to the other Party.

2. Arbitration shall be conducted by a tribunal composed of three arbitrators. One arbitrator shall be nominated by Nepal, one by India, with neither country to nominate its own national and the third arbitrator shall be appointed jointly, who, as a member of the tribunal, shall preside over such tribunal. In the event that the Parties are unable to agree upon the third arbitrator within ninety (90) days after receipt of a proposal, either Party may request the Secretary-General of the Permanent Court of Arbitration at The Hague to appoint such arbitrator who shall not be a national of either country.

3. The procedures of the arbitration shall be determined by the arbitration tribunal and the decision of a majority of the arbitrators shall be the decision of the tribunal. The proceedings of the tribunal shall be conducted in English and the decision of such a tribunal shall be in writing. Both the Parties shall accept the decision as final, definitive and binding.

4. Provision for the venue of arbitration, the administrative support of the arbitration tribunal and the remuneration and expenses of its arbitrators shall be as agreed in an exchange of notes between the Parties. Both the Parties may also agree by such exchange of notes on alternative procedures for settling differences arising under this Treaty.

\section{Article 12}

1. Following the conclusion of this Treaty, the earlier understanding reached between the Parties concerning the utilization of the waters of the Mahakali River from the Sarada Barrage and the Tanakpur Barrage, which have been incorporated herein, shall be deemed to have been replaced by this Treaty.

2. This Treaty shall be subject to ratification and shall enter into force on the date of exchange of instruments of ratification. It shall remain valid for a period of seventy five (75) years from the date of its entry into force.

3. This Treaty shall be reviewed by both the Parties at ten (10) years interval or earlier as required by either Party and make amendments thereto, if necessary.

4. Agreements, as required, shall be entered into by the Parties to give effect to the provisions of this Treaty.

IN WITNESS WHEREOF the undersigned being duly authorised thereto by their respective governments have hereto signed this Treaty and affixed thereto their seals in two originals each in Hindi, Nepali and English languages, all the texts being equally authentic. In case of doubt, the English text shall prevail. 